\title{
Komposisi Kimia dan Komponen Serat Berbagai Jenis Pakan Lokal yang Berasal dari Habitat Asal Kuskus dan Penangkaran
}

\author{
M. Kayadoe, J. F. Koibur dan H. Warmetan \\ Program Studi Peternakan, Fakultas Peternakan Perikanan dan Ilmu Kelautan \\ Universitas Negeri Papua \\ Jl. Gunung Salju, Amban Kode Pos 98314 Papua Barat \\ E-mail : marthakayadoe837@gmail.com
}

\begin{abstract}
ABSTRAK
Penelitian ini mengkaji komposisi kimia dan komponen serat pada berbagai pakan lokal kuskus yang bersumber dari habitat asalnya maupun di penangkaran. Penelitian ini merupakan penelitian deskriptif dengan menggunakan 11 jenis pakan kuskus yang terdiri dari 3 jenis pakan asal habitatnya (tumbuhan kayu yaitu : Pometia pinnata, Pongamia pinnata dan Intsia bijuga), 8 jenis tumbuhan asal penangkaran (3 jenis tumbuhan non kayu yaitu Ipomoea aquatica, Ipomoea batatas, dan Brassicia spp. dan 5 jenis buah-buahan yaitu Carica papaya, Musa paradisiaca, Artocarpus integra, Averhoa carambala, Persea americana). Analisis proksimat dan van Soest dilaksanakan di Laboratorium Nutrisi dan Makanan Ternak FPPK dan Laboratorium Teknologi Hasil Hutan di Unipa, dan BalitnakBPPP Ciawi, Bogor. Hasil penelitian menunjukkan bahwa jenis pakan yang bersumber dari habitat asalnya memiliki komposisi kimia (nilai gizi) yang lebih baik daripada jenis pakan yang berasal dari penangkaran. Komponen serat lebih tinggi dikandung pada jenis pakan dari habitat asalnya, daripada di penangkaran. Hal ini sesuai dengan penelitian di Papua New Guinea yang menyatakan bahwa kuskus di penangkaran perlu mendapatkan pakan yang berserat, baik untuk mengatasi peradangan pada usus dan juga memungkinkan daya tahan hidup lebih lama. Simpulan dari penelitian ini adalah kuskus yang dipelihara di penangkaran yang diberi dominan pakan buah-buahan ternyata perlu diberikan pakan dari habitat asalnya karena potensi gizi maupun komponen serat yang lebih tinggi.
\end{abstract}

Kata kunci: komponen kimia, komponen serat, pakan, habitat asal, penangkaran

\section{Chemical Composition And Fiber Components Of Various Types Of Feed Derived From Native Habitats And Captivity (Cage)}

\begin{abstract}
The study was to examine the chemical composition and fiber components in various local feed sourced from native habitats and in cage. The research use 11 type of feed that rested on three types of feed native habitats (3 types of timber plants: Pometia pinnata, Pongamia pinnata, and Intsia bijuga and 8 types of feed from kuskus cage are three types of non wood plants: Ipomoea aquatic, Ipomoea batatas, and Brassicia spp., and five types of fruits: Carica papaya, Musa paradisiaca, Artocarpus integra, Averhoa carambala, Persea americana). Proximate and van Soest analysis was analized in the Feed and Nutrition Laboratory Fakultas Peternakan Perikanan dan Ilmu Kelautan Unipa, The laboratory of Forest Product Tecnology Fakultas Kehutanan Unipa, and BPT Ciawi, Bogor. The result showed that the type of feed sourced native habitats has a chemical compositions beter than that type of feed from captivity (cage). Besides higher fiber components contained on type of feed from his native habitat. These were consistent with research in Papua New Guinea that fibrous feed either need to overcome intestinal infleminations and possibly longer survival. The conclusions of this study were rear edin captivity possum that given the dominant feed fruits turned out to be given food from his native habitat because of higher potential for nutrient and fiber components.
\end{abstract}

Key words: chemical composition, fiber components, feed, native habitats, captivity 


\section{PENDAHULUAN}

Keanekaragaman hayati di Indonesia terdiri dari flora dan fauna yang memiliki jumlah cukup besar di dunia (Donner, 1987) termasuk yang berada dalam kawasan Papua dengan cirri khas tersendiri. Kelompok fauna endemik Papua sebagai mamalia darat yang berada di Kawasan Papua ada tiga sub kelas yaitu Prototheria (petelur), marsupialia (berkantung) dan Eutheria (Dimomonmau, 2000). Secara khusus kuskus termasuk satwa marsupialia (mamalia berkantung) dan dikenal sebagai satwa herbivora.

Berdasarkan identifikasi pakan kuskus ternyata antara pakan yang dikonsumsi oleh kuskus yang hidup di alam berbeda dengan yang lazim diberikan oleh pemelihara pada kuskus di penangkaran. Lebih banyak kuskus di alam mengkonsumsi pucuk-pucuk daun (tumbuhan kayu) yang terdapat di kawasan hutan sedangkan kuskus di penangkaran lebih banyak diberikan buahbuahan dan tanaman sayuran (tumbuhan nonkayu). Murwanto et al. (2008) menyatakan bahwa $71,81 \%$ pakan kuskus di penangkaran berupa buah-buahan sedangkan $28,19 \%$ hanya daun-daun.

Berdasarkan wawancara dengan masyarkat pemelihara kuskus di Manokwari, ternyata daya tahan hidup kuskus rata-rata dapat bertahan paling lama 2 minggu. Pengamatan lain melaporkan paling lama kuskus hidup di penangkaran 4 bulan. Selain itu laju pertambahan bobot badan sangat lambat yaitu rata-rata $3,55 \mathrm{~g} /$ ekor/hari. Pertambahan bobot badan yang lambat ini diduga merupakan salah satu penyebab kuskus tidak bertahan hidup lama dengan kondisi proporsi pakan yang berbanding terbalik antara kehidupan di alam dengan di penangkaran.

Oleh karena itu, untuk mengetahui lebih lanjut penyebab daya tahan hidup tidak lama pada kuskus di penangkaran, maka perlu pengkajian awal tentang komposisi kimia dan komponen serat pakan kuskus baik yang dikonsumsi di habitat asalnya (di kawasan hutan) maupun yang lazim diberikan oleh pemelihara (jenis pakan buah- buahan dan tumbuhan sayuran).

\section{MATERI DAN METODE}

Penelitian ini dilaksanakan di Laboratorium Nutrisi dan Makanan Ternak Fakultas Peternakan Perikanan dan Ilmu Kelautan, Laboratorium Teknologi Hasil Hutan, Universitas Papua di Manokwari dan di Laboratorium Balai Penelitian Ternak BPPP Ciawi yang berlangsung dari tanggal 11 Februari sampai dengan 20 Juli 2013.

Bahan-bahan yang digunakan dalam penelitian adalah bahan-bahan makanan kuskus dari habitat asalnya (di alam) berupa pucuk daun tumbuhan hutan : Pometia pinnata, Pongamia pinnata, dan Intsia bijuga sedangkan bahan makanan kuskus di penangkaran berupa tumbuhan nonkayu meliputi Brassicia spp, Ipomoea batatas, Ipomoea aquatica, dan jenis buah-buahan meliputi : Carica papaya, Musa paradisiaca, Persea americana, Artocarpus integra, Averhoa carambola, dan peralatan yang digunakan oven, perangkat alat untuk analisis proksimat, perangkat alat untuk Analisis Van Soest, alat untuk analisis kandungan energi dan timbangan.

Preparasi sampel dilakukan dengan menyiapakan sampel bahan makanan kuskus dari segar sampai ke proses pengeringan. Pengeringan berlangsung 2 tahap yaitu pengeringan dengan oven pada suhu $60^{\circ} \mathrm{C}$ (selama 3 hari proses pengeringan) dan $105^{\circ} \mathrm{C}$.

Pengamatan pertama dilakukan pengeringan sampel pakan pada suhu $60^{\circ} \mathrm{C}$. Setelah itu digiling untuk dilanjutkan pada tahap analisis untuk melihat komposisi kimia dan komponen serat bahan makanan kuskus. Sebagian sampel diambil juga untuk analisa kandungan bahan kering $105^{\circ} \mathrm{C}$.

\section{HASIL DAN PEMBAHASAN}

\section{Komposisi Kimia}

Kandungan nutrien atau komposisi kimia dari bahan makanan kuskus dari habitat asalnya berupa pucuk daun Pometia 
Tabel 1. Komposisi kimia berbagai bahan pakan lokal untuk kuskus

\begin{tabular}{|c|c|c|c|c|c|c|c|c|}
\hline \multirow[b]{2}{*}{ Jenis Sampel } & \multicolumn{8}{|c|}{ Komposisi Kimia (\%) } \\
\hline & $\begin{array}{l}\text { Bahan } \\
\text { kering }\end{array}$ & $\begin{array}{l}\text { Protein } \\
\text { kasar }\end{array}$ & $\begin{array}{l}\text { Serat } \\
\text { kasar }\end{array}$ & $\begin{array}{l}\text { Lemak } \\
\text { kasar }\end{array}$ & Abu & $\mathrm{Ca}$ & $\mathrm{P}$ & $\begin{array}{l}\text { Energi } \\
\mathrm{kcal} / \mathrm{kg}\end{array}$ \\
\hline $\begin{array}{l}\text { Pucuk daun matoa } \\
\text { (Pometia pinnata) }\end{array}$ & 27,97 & 7,32 & 24,49 & 7,46 & 4,08 & 0,76 & 0,09 & 4643 \\
\hline $\begin{array}{l}\text { Pucuk daun kayu besi } \\
\text { pantai } \\
\text { (Pongamia pinnata) }\end{array}$ & 16,51 & 24,55 & 35,55 & 9,37 & 7,30 & 0,97 & 0,12 & 4411 \\
\hline $\begin{array}{l}\text { Pucuk daun kayu besi } \\
\text { gunung } \\
\text { (Instia bijuga) }\end{array}$ & 17,0 & 20,90 & $\begin{array}{l}27,, 8 \\
7\end{array}$ & 11,30 & 7,61 & 1,28 & 0,23 & 4519 \\
\hline $\begin{array}{l}\text { Daun kangkung } \\
\text { (Ipomomea aquatica) }\end{array}$ & 9,27 & 45,67 & 11,67 & 9,31 & 10,73 & 0,51 & 0,56 & 4034 \\
\hline $\begin{array}{l}\text { Daun sawi } \\
\text { (Brassicia sp.) }\end{array}$ & 9,29 & 38,71 & 13,49 & 10,74 & 13,86 & 1,81 & 0,68 & 4325 \\
\hline $\begin{array}{l}\text { Daun ubi jalar } \\
\text { (Ipomoea batatas) }\end{array}$ & 13,82 & 30,17 & 13,33 & 8,78 & 9,79 & 0,51 & 0,48 & 4270 \\
\hline Carica papaya (рарауа) & 10,75 & 6,50 & 6,71 & 3,64 & 5,42 & 0,13 & 0,13 & 3541 \\
\hline $\begin{array}{l}\text { Musa paradisiaca } \\
\text { (pisang) }\end{array}$ & 20,79 & 5,30 & 4,53 & 0,98 & 5,49 & $<0,01$ & 0,09 & 3688 \\
\hline $\begin{array}{l}\text { Artocarpus integra } \\
\text { (nangka) }\end{array}$ & 13,36 & 10,56 & 7,55 & 2,08 & 5,61 & $<0,01$ & 0,08 & 3890 \\
\hline $\begin{array}{l}\text { Averhoa carambola } \\
\text { (belimbing) }\end{array}$ & 8,52 & 6,21 & 12,85 & 7,44 & 4,48 & 0,14 & 0,13 & 3782 \\
\hline $\begin{array}{l}\text { Persea Americana } \\
\text { (advokat) }\end{array}$ & 12,70 & 7,77 & 13,54 & 39,82 & 5,44 & $<0,01$ & 0,07 & 5535 \\
\hline
\end{tabular}

Tabel 2. Komponen serat pada berbagai bahan makanan kuskus

\begin{tabular}{lccccc}
\hline \hline \multicolumn{1}{c}{ Jenis Bahan Makanan Kuskus } & Selulosa & NDF & ADF & Lignin & $\begin{array}{c}\text { Hemiselulosa } \\
\text { (NDF - ADF) }\end{array}$ \\
\hline $\begin{array}{l}\text { Pucuk daun matoa (Pometia } \\
\text { pinnata) }\end{array}$ & 16,54 & 41,14 & 40,63 & 17,91 & 0,51 \\
$\begin{array}{l}\text { Pucuk daun kayu besi } \\
\text { pantai(Pongamia pinnata) }\end{array}$ & 31,72 & 61,01 & 55,82 & 23,85 & 5,19 \\
$\begin{array}{l}\text { Pucuk daun kayu besi gunung } \\
\text { (Instia bijuga) }\end{array}$ & 22,05 & 49,12 & 35,57 & 9,09 & 13,55 \\
Daun kangkung (Ipomomea & 19,56 & 52,06 & 44,20 & 19,03 & 7,86 \\
aquatica) & & & & & \\
Daun sawi (Brassicia sp.) & 21,77 & 31,62 & 31,30 & 8,74 & 0,32 \\
$\begin{array}{l}\text { Daun ubi jalar (Ipomoea batatas) } \\
\text { Carica papaya }\end{array}$ & 19,58 & 49,22 & 48,85 & 21,33 & 0,37 \\
Musa paradisiacal & 7,71 & 8,71 & 8,08 & 0,78 & 0,63 \\
Artocarpus integra & 3,17 & 11,62 & 4,74 & 2,36 & 6,88 \\
Averhoa carambola & 7,89 & 13,92 & 7,83 & 8,70 & 6,09 \\
Persea Americana & 13,43 & 32,72 & 32,01 & 17,67 & 0,71 \\
\hline
\end{tabular}

pinnata, Pongamia pinnata, dan Intsia bijuga, dan bahan makanan kuskus di penangkaran berupa tumbuhan non kayu meliputi Brassicia spp, Ipomoea batatas, Ipomoea aquatica, dan jenis buah-buahan meliputi : Carica papaya, Musa paradisiaca, 
Persea americana, Artocarpus integra, Averhoa carambola disajikan pada Tabel 1.

Berdasarkan Tabel 1 ternyata hasil kajian ini menunjukkan bahwa bahan makanan kuskus yang berasal dari tumbuhan kayu yaitu yang berasal dari habitat asalnya ternyata mengandung serat kasar lebih tinggi dibanding yang biasa diberikan dalam penangkaran (buah-buahan) maupun yang berasal dari tumbuhan nonkayu (sayursayuran). Selain itu di antara pucuk daun tumbuhan kayu tersebut (3 jenis) ternyata pucuk daun kayu besi pantai (Pometia pinnata) memiliki kandungan serat kasar dan protein kasar lebih tinggi dibanding pucuk daun matoa maupun kayu besi gunung.

Tumbuhan Pongamia pinnata banyak ditemukan di sepanjang pantai dan hidup bergerombol (Heyne, 1987 dalam www foreibanjarbaru.or.id), memiliki sifat yang tahan terhadap salinitas dan udara terbuka, cepat tumbuh, dan berbuah. Buah (biji) dari tumbuhan ini dapat dimanfaatkan sebagai biodiesel, sedangkan pemanfaatan pucuk daunnya bisa sebagai pakan, karena nilai gizi cukup baik.

Nilai manfaat dari kandungan nutrisi pakan menentukan nilai guna untuk produksi seekor ternak termasuk satwa. Hal ini sesuai pendapat Anggorodi (1990) bahwa zat-zat makanan yang ada dalam bahan makanan tersebut diubah dalam tubuh ternak atau satwa menjadi daging, susu, telur, wol, energi dan lainnya. Performa ternak ditunjukkan dari produksinya yang baik dan semuanya itu tercapai bila ternak atau satwa mendapat ransum yang sempurna.

\section{Komponen Serat}

Hasil analisis bahan makanan kuskus terhadap bagian atau komponen-komponen seratnya disajikan pada Tabel 2 berikut.

\section{Tabel 2.}

Berdasarkan Tabel 2 diatas ternyata kandungan selulosa pada tumbuhan kayu (3 jenis) atau bahan makanan yang bersumber dari habitat asal kuskus lebih tinggi dibanding kelompok buah-buahan ( bahan makanan yang diberikan di penangkaran) maupun tumbuhan nonkayu (sayur-sayuran). Tingginya kandungan selulosa seiring dengan tingginya kandungan serat kasar.

Selulosa dan hemiselulosa terdiri dari banyak molekul glukosa dan molekulnya tidak bercabang. Komponen molekul yang banyak di dalam selulosa sulit dicerna. Fungsi utama dari selulosa ini untuk menyediakan bahan bulky dan tidak dapat dicerna sehingga dapat meningkatkan efisiensi kerja saluran usus, sedangkan fungsi hemiselulosa untuk mengabsorpsi air dan membentuk gel dan memperbesar volume bulk yang berperan sebagai laksatif (Anggorodi, 1990).

Berkaitan dengan pakan kuskus dari habitat asalnya yang ternyata mengandung selulosa lebih tinggi daripada selulosa dalam pakan di penangkaran, ini membuktikan bahwa kuskus perlu mendapat pakan yang mengandung serat kasar tinggi.

\section{SIMPULAN}

Kandungan nutrien pada pakan kuskus yang bersumber dari habitat asalnya (tumbuhan kayu) yaitu Pometia pinnata, Pongamia pinnata dan Intsia bijuga menunjukkan nilai yang lebih tinggi dibanding dengan jenis pakan yang bersumber dari penangkaran (tumbuhan non kayu dan buah-buahan). Komponen serat tertinggi dikandung pada jenis pakan yang bersumber dari habitat asalnya yaitu Pometia pinnata, Pongamia pinnata dan Intsia bijuga.

\section{SARAN}

Perlu dilakukan penelitian lanjutan (sebagai penelitian tahun ke-2) untuk dalam tingkat konsumsi dan kecernaan untuk mendapatkan formula yang tepat sebagai pakan kuskus. Perlu dikaji pengujian palatabilitas kuskus terhadap pakan yang diberikan.

\section{DAFTAR PUSTAKA}


Dimomonmou, P.A. 2000. Eksplorasi Jenis Kuskus di Pulau Moor kecamatan napan Wainami Kabupaten Nabire. Faperta Uncen. Manokwari.

Donner, W. 1987. Land Use and Enviroment in Indonesian. Honolulu University of Hawaii Press.

www. foreibanjarbaru or.id/wp. Deskripsi Tanaman Malapari (Pongamia PinnataL).PIERRE.
Murwanto, A.G., M. Kayadoe, S.D. Djoko Rhardjo, C. Sadi, dan S. Karapa. 2008. Budidaya Kuskus dalam Rangka Difersifikasi Ternak Lokal Papua. Jur. Ilmu Ilmu Peternakan Brawijaya. Vol.18 No.3. Fakultas Peternakan Universitas Brawijaya. Malang. 